\title{
Communication and the Natural Social Order
}

\section{Olga Dmitrievna Shipunova \\ Dmitry Ivanovich Kuznetsov}

Department of Philosophy, Humanitarian Institute, Peter the Great St.Petersburg Polytechnic University, St. Petersburg, Russian Federation

\section{Doi:10.5901/mjss.2015.v6n3s3p265}

\section{Abstract}

The article deals with the analysis of the social order conditions, which are natural for a human and which are explained through personification of cultural meanings and locality that has ethnic context. Generalization of knowledge about the socionatural relationships in a person's life has been performed using the principle of consistency and socio-cognitive approach. The multifaceted nature of dynamics of the mentality, on which the trust to authorities is based, and which draws upon the subconsciously normalized ethnic consciousness, is emphasized. It is shown that the main means of total control in the context of the natural social order is the indirect metadiscursive communicative impact through the introduction of semantic settings hidden behind the outer side of symbolic and speech practices. In conclusion, the stability of the non-violent mechanism for maintaining the social order in spite of ongoing political and cultural transformations is emphasized. The destruction of the natural social order is made possible as a result of discursive provocations shifting the basic semantic and value-related references that are inherent in the subconscious.

Keywords: social order, trust, local context, ethnic consciousness, metadiscourse of communication.

\section{Introduction}

In everyday life, social order is associated with the administrative and legal framework of the government, which directs the activities of institutions that support a specific regulation of public and private life. Along with the progress of the information age with its interactive dynamics of networks, the idea of the social order is problematized. The network reality produces association with the most open communications in the form of free associations of individuals. New ways to form the social order at the level of mobile networks occur, which are based on informal norms and values (Castells, 2000-2004).

Following the declaration of freedom of choice, sociologists refer to the social systems self-organization processes, which are of the natural for people and, therefore, non-violent nature. The social order is interpreted through locality (the scene) having a specific context, and personification of cultural meanings (Giddens, 1986). The fact of orderliness of the systems of perception and action in human community is described with the societal process concept, which consists in orientation and sustainable reproduction of social and inter-individual interactions within a meaningful interval and cultural space. The social order is based on the reproduction of culture through the system of knowledge and educational institutions in the interests of ruling elites (Bourdieu, 1991). The key role of compliance of the behavior of individuals and different strata of the society with the norms accepted in the given social system is emphasized (Habermas, 2010). Uncertainty of trust structures as the most common and the least significant basis of social cohesion (Hosking, 2015) forces us to analyze the hidden grounds of the communicative practice in communities, specific beliefs, life goals, which are formed spontaneously in line with the emotional belonging to a reference group (Taylor, 1985; Maclntyre, 1981).

The connection of the mentality dynamics and the social order, which is behind the structures of trust, is of multifaceted nature. We find it efficient to clarify this connection through the combination of the systematic goal-setting of the modern science in the study of the living conditions natural for humans and the normative principle of community selforganization, according to which the established semantic orientations in behavior are set, and the practices of indirect communication in the processes of personality self-determination unfold. The article aims to consider the metadiscourse of communication as a basic condition of mental dynamics and to correlate the nonviolent strategy of social order formation with this condition. 


\section{Literature Review}

Common philosophical and sociological interpretations of the social order are based on the idea of the general form of the society existence, which in ancient tradition was related to the idea of the Public Good. More recent percepts of the social order are based on the idea of the natural human aggressiveness, which in the concepts of a social contract is restricted by the introduction of civil law. State power and social order are understood as a technique to manage natural selfishness and violence. In modern literature, state power is commonly understood as a subject that has violence monopoly (Barzel, 2001; Bueno de Mesquita et al., 2003; Myerson, 2008; Olson, 1993).

D. North, J. Wallis, B. Vayngast consider various social orders as accidentally invented ways to limit the natural human aggression in the situation of conflict, giving the task of preserving social order a new communicative aspect that allows emphasizing the role of cultural and social codes in the social order formation. On the example of the large historical material, the authors show steady sophistication of these codes and formulate the problem associated with the threat to their simplification. The price paid for the unsuccessful resolution of conflicts, the authors say, is the decreasing mutual responsibility and trust. An example is the increasing frequency of aggressive contacts with immigrants in modern Europe (North et al., 2009a).

An analysis of the evolution of social structure in terms of the technique of natural human aggression control allows the authors to formulate the concept of a natural state and to reproduce its features in various regions. At the same time, an analysis of the internal dynamics of relationships in a natural state in the modern terms of "open access" allows interpreting the social order in the context of the communication culture development (North et al., 2009b).

The indicators of the communication culture are: access to communication means, freedom of expression, and use of communication means. The attribute of more advanced communication cultures, according to Inkelsu and McLuhan, is the unlimited opportunity to represent individual and group opinions in the public space. Restriction of the fundamental parameters of the communication culture leads to the establishment of barriers in the public dialog and is an indicator of the already existing social inequality. The immediate interdependence of the verbal and behavioral aspects in a verbally oriented culture is emphasized: what has been said is likely to be translated in the actions of individuals. At the same time, by assigning social restrictions and assessments solely to the behavioral aspect, the written cultures of the West relieve the expression aspect. Freedom of discourse is conceived as a value, and its contents are not subject to regulatory assessment on the "acceptable - unacceptable" scale (Inkeles, 1950; McLuhan, 1967).

With the proliferation of network communication, the external (institutional) regulation weakens in the modern society. Temporal resources taking an equal place along with material and information resources complicate the social dynamics (Fukuyama, 1995). In this case, the social effectiveness of action is associated not only with access to "new media", but also with the ability of an individual to recognize the most relevant topics, use the advanced communication and cognitive strategies of transformation of heterogeneous information into knowledge (Manovich, 2001).

A condition of the sociocultural order in verbally oriented cultures is the control of public dialog in accordance with the principles of discursive ethics (Habermas, 1983). The internal constraints that manifest themselves at the level of the discourses conflict come to the foreground, as noticed by E.A. Kozhemyakin. In the interaction, this conflict is generated by the collision of different sound points of view, but above all by the mismatch of socially significant discourses. Along with ample opportunities for self-expression, discourse polyphony complicates both the use of common standards for interpretation and evaluation of "media content" and the possibility to be heard (Kozhemyakin, 2011). Speaking about the conflict of interpretations, P. Ricœur particularly stressed the need to correlate the semantics of desires and targeted intention and to take into account the subjective process of understanding signs and meanings (Ricœur, 1974/2010).

Communicative practice studies emphasize that not the entire semantic canvas of the life world of a human can be expressed with the language. The content of the phenomenon of communication is not limited to the conversation only and is manifested in different socio-cultural and socio-technical environments. Communication in its existential (socioontological) aspect extends far beyond the usual everyday life in the horizon of text and speech practices (Morley, 2007; Moores, 2012; Klyagin et al., 2014).

The modern hermeneutics paradigm identified in the papers by G.-G. Gadamer (Gadamer, 1989), P. Ricœur (Ricœur, 1974/2010), E. Betti (Betti, 1962/2011) highlights the fact that a word (and, therefore, discourse) just makes understanding possible by creating a necessary condition for finding the meaning. The process of understanding is not just interpretation. It assumes intensive mental activity in the form of evaluative assigning of meaning. The scale of communication manifestations -from simple interjections to complex informational and semantic interactions -only partly can be attributed to the space of words, if word is treated as part of language. In culture, however, it is word that relates to the special kind of an ontological model of the incarnation (or disguise) of the ultimate meaning of the boon sequencing. (Klyagin et al., 2013). 
We associate the existence level of such meaning with the metadiscourse of communication, thus emphasizing the hidden and ambiguous interdependence between the discursive and behavioral practice that continues to be one of the main features of the communication culture and in the network society.

\section{Materials and Methods}

We see the prospects of the research in the synthesis of the knowledge of socio-natural relationships in human life and the application of the principle of systemic and socio-cognitive approach in the development of the idea about the natural social order.

The systematic paradigm and the principle of locality allow reconciling the viewpoints of different sciences on the nature of a natural state. For example, Friedrich Ratzel in the early XX century determined the relationship of territory as such and human societies living in the area, with their specific forms of political and economic order, as the anthropogeography subject. His follower Savitsky initiated the systematic study of territory, the data of physical geography, climatology, biology (biogeography), soil science, and the history of human society (Glebov, 2010).

The new systematic paradigm considered territory not separately, but in combination with natural physical data and the anthropogenic circle. Studies of this unity required synthesis of the socio-historical and geographical viewpoints, ability to combine the vision of socio-historical environment and of the territory occupied by it. To highlight the essence of systemic vision of a region, Savitsky proposed the concept developmental place, which he defined as "broad co-living of living beings that have adapted to each other and to the environment and adapted it to themselves" (Savitsky, 1921) . Developing the concept of "developmental place", Savitsky presented Russia geopolitically as a special type of civilization, established on the basis of several components -the Aryan-Slavic culture, the Turkic nomadic, and the Orthodox tradition.

In ethnology and historical geography, the principle of locality fixes the connection of ethnic tradition of perception and thinking with the landscape of the life world of a community. Ethnicity as system integrity is connected to the dynamics of the biosphere, in particular to the use of technology, to natural and anthropogenic modification of landscapes, as L.N. Gumilev noted. Not only humans, but also ethnic groups have homeland, which is defined by a combination of landscapes, where they have formed a certain socio-natural system (Gumilev, 1994). However, not every territory can be a developmental place for an ethnic group. True developmental places are territories where two or more landscapes are combined. Therefore, the basic processes of ethnogenesis in Eurasia have occurred: a) in the eastern part -the combination of mountain and steppe landscapes; $b$ ) in the west -the forest and meadow landscapes (fields in the Volga-Oka interfluve area); c) in the south -the steppe and oases (Crimea, Central Asia); d) in the north -wooded tundra and tundra. And not a single nation or culture has appeared in the territory of taiga from Lake Onega to the Sea of Okhotsk. All that has appeared there was brought from either the south or the north. Clean, continuous steppe also does not allow development. This is the steppe from Altai to Carpathians, which was settled by peoples who had formed in other regions, such as Mongolia -a country with high relief and varied landscapes (Gumilev, 1994).

The system of geography of the end of XX century represented by the Lund School of Time Geography emphasized the analysis of urban sprawl in terms of space and time, correlated with the density of life and perception of innovation. The founder of this school, Hägerstrand, identified certain limitations that bind the limits of human activities in space and time as the material axes of human being. The most important limits according to him were: 1) the human environment and corporeality severely restricting the movement and perception abilities; 2) finiteness of human life as a time resource deficit; 3 ) restrictions of physical capacity of space-time. These natural restrictions of human being are seen as resources involved in the processes of forming the social order, as systems of interactions between people are formed around them (Hägerstrand, 1975).

Like Savitsky's concept of "developmental place", Hägerstrand's time geography emphasizes the basic value of the natural conditions of human life, which include the system connection of landscape and ethnic community as a group of people. At that, landscape is understood as an earth surface plot bordered by natural boundaries and being a mutually conditioned collection of objects and phenomena, which is typical for a considerably large territory and is inextricably linked with this shell. L.N. Gumilev stressed that such natural basis of ethnic community is determined by the term "developmental place" similar to the concept of "deposit occurrence" in geology (Gumilev, 1994).

Though ethnic integrity coincides with neither a family unit, nor the level of production and culture, it, however, defines the context of any personal action. Ethnic culture embodied in the language allows drawing an isogloss on a geographic map -the line limiting the geographical distribution of a certain linguistic phenomenon, which is correlated with the place and society. Thus, each person is placed in the language boundaries, and the nation as a whole - in natural territorial boundaries. However, this feature is also not exhaustive, as nations, speaking different languages can 
peacefully co-exist within the same natural boundaries.

Isogloss, as a discursive boundary of the ethnic community, points at another temporal aspect of reviewing the conditions of the social order, which is associated with the semantics and symbolism of the community translating basic orientations in the worldview and evaluation of activities. Therefore, a systematic approach to natural conditions of the social order should also include the process of social inheritance. M.K. Petrov considered two cultural phenomena as universals of the social inheritance: timeless sign and finite activity. According to M.K. Petrov, the sign is the only candidate for the role of a "social gene", which "bears the meaning and is the basis of its successive changes, the result, address, and reason of communication." Timelessness and impersonality of the sign provides the cultural tradition with independent and objective nature of eternal existence. Tradition, in turn, configures and restricts the physical and biological existence of an individual with the semantic framework of the lifeworld. "Transmission of sociality as the present total of circumstances without involving the sign is as impossible as transfer of species traits without involving the gene", wrote M.K.Petrov. However, the effect of the social code does not start with a seed bearing the bio-code of its parents, but with a baby through programming it for a certain activity. The roots of activity as a cultural universal of social inheritance are seen in the active adaptive nature of all living things, in ensuring the physical existence of an individual and the society. However, a society will perish as a society without the sign, making the living generation to live under the rules of the animal world (Petrov, 2004).

Social coding forms the natural condition of the non-violent social order. Being a material for speech practices and being involved in all kinds of semantic games, the sign symbolism becomes a means of mental dynamics, as well as a means of the cultural aspect increment. The issue of relationship between mental and cultural structures in the form of the problem of "capacity" (Petrov, 2004) of a real individual perceiving cultural norms and meanings is in line with the modern concepts of the discursive mechanism of social memory, in which the role of the sphere of concepts is emphasized as an unspoken limiter and regulator of social behavior. Each linguistic and cultural community seeks to limit the self-determination of an individual with hard-coded cognitive framework to minimize his freedom of maneuver in the cultural space.

Limitations of perception are seen in the individually decorated way of thinking and acting, which is ambiguously correlated with the era, in which the person lives. The style of behavior is in a sense self-contained with respect to the situation, implies a free choice, but ultimately is socially conditioned. Herewith, the implicit conditions are important, which define the size of understanding in the cultural and linguistic traditions. The terms of the ability to understand are in line with the concept of mentality, which indicates the potential boundaries of semantic communication that has different levels and is based not only on the discourse. Intuitive understanding (grasp, capture) of the meaning acts as an implicit cognitive-emotional channel of influence in a community. The same semantic metadiscourse channel is found in building barriers of perception of meaning. P. Bourdieu emphasized the existence of such barriers with the concepts habitus, social field.

The complexity of the natural bases of the social order was described by E. Durkheim by denoting the role of the collective unconscious in the human and society life. A huge reservoir of paradigms non-fixed by the consciousness, intuitions, preferences lies in the pragmatics of speech as a special reality of preunderstanding and preknowledge, in which existentially significant subjective and cultural meanings are fused together. This reality, which is not specified in any way at first glance, is able to generate emotion, the power of which dates back to the ancient layers of the human psyche.

The single emotion of empathy "We" constitutes an existential basis of unity of community. Its reverse side is the unaccountable confusion and emotional rejection of "Strangers" (Porshnev, 1971). As shown by the modern social practice, the intention of rejection as a communication barrier cannot be removed even in the circumstances of the declared mindset for the discursive ethics and tolerance in a deliberative democracy. T. Van Dijk in the book "Discourse and Power" showed that this intention is translated into discursive formations of the linguistic tradition (Van Dijk, 2008b). The unity of community also needs perspective, which is also unconsciously emotionally perceived by the subject primarily in terms of the safety of life against the background of the conservation of the community and the usual social order. Violation of this perspective is associated with persistent subconscious resistance to the destruction of the cultural and ethnic environment.

Tradition is the most important social mechanism for the preservation of norms, values, culture samples, which provides a semantic canvas of the life of society and communication between generations, and which combines wide public recognition with acceptance of implicit social control. Since the subject is always in the sociocultural environment, which determines the conditions of life and the context of its understanding, a fundamental role in the self-determination of an individual belongs to identification schemes that explicitly and implicitly reflect the interweaving of historical and ethnic features, which are not identical in different regions of residence. 
The difference between identification programs, which is bound to the difference between the historical and cultural destinies of the peoples of the East and the West, is beginning to be explored in the context of the civilizational approach to the history of the human society. The idea of the existence of different civilizations appears in Europe in the context of European awareness of their difference from the world of Islam (Hay, 1968; Wintle, 1999; The Idea of Europe, 2002). In the early twentieth century, this idea was broadly interpreted within the concept of "total geographical regions", which singled out the "environmental" aspects of the unity of Eurasia (Bassin, 1991; Savitsky, 1921).

At the end of XX century, the shaped spatiotemporal paradigm of cultural geography was formed, which took into account the relationship of the subjected living environment of humans with the macro level of its understanding, represented by the culture and the worldview. From this perspective, the natural geographical spaces are formed as a human life environment and transformed in the area of interaction of various driving forces of the nature and society components. A specific cultural landscape is embodied on the Earth's surface in accordance with the motivational and value-related spheres of the society (Grossman, 1977; Animitsa \& Sharygin, 2005; Ragulina, 2013).

The communicative practice of nonviolent maintenance of the social order is associated just with the motivational and value-related sphere. Self-organization of life in a community is based on intuitive connection of single emotion and general idea or doctrine, according to which the truth and the lie in the perception of the world and mutual relations in a society are delimited. A certain archetype of the social order is formed in the community, which unconsciously guides motives, thoughts, and actions of an individual.

The metadiscourse of the communication is something that is not mentioned, but is intuitively understood, done, and evaluated as the correct and proper. Most clearly, the existence of such a metadiscursive basis of communication in the community is manifested in contacts with other ethnic groups. Contact with another behavior standard is surprising and causes intuitive and emotional rejection, which generates a deeper ground for misunderstanding. For example, the Scythians did not accept the bacchanalia of the Greeks, the Jews hated the Romans because they ate pork, knights resented the Arabic custom of polygamy, and the Arabs -open faces of women. The strength of an ethnic stereotype is huge because all members of an ethnic group perceive it as the only one worthy, and all the others -as "savagery." That is why European colonizers called Indians, Africans, Mongols, and Russians savages, although the same could be applied to the Englishmen (Gumilev, 1994).

An ethnic stereotype is defined by a tacit norm, which is perceived by each person as a natural (innate) way of attitude to the surrounding natural world and as a condition of free communication in this community.

\section{Results}

Natural grounds of nonviolent social order are most clearly emphasized by the general principle of locality. However, the spatiotemporal measurement of historical socio-cultural events always has multiple layers, as it affects the semantic measurement of the social reality associated also with the existence of symbolic forms. The target of cultural symbols is to preserve and translate meanings in the subjective process of perceiving, reading, and understanding a cultural form.

The history of human culture in its objective sense of the world of artifacts and in the meaning of the specific features of the individual psyche is associated with the processes of storage, production, and translation of the generic experience, which gives reasons to assert that social coding is the most important ontological condition for the existence of any human community, each individual, and culture as such. The basis of the social order is formed by the generalized codes of communication -the code of power and the code of truth, which define the semantic canvas perceived by each member of the community (Luhmann, 1979). This canvas is an implicit, but rather specific condition of sociocultural integrity, which can be associated with the metadiscourse of communication. The typified code of truth inherent in the tradition defines the existential sense of existence including spatial and behavioral orientations. With regard to selforganization of community, the uncertainty of the code of truth leads to the tenuity of substantiation of the social order, which in turn becomes problematic and unnecessary.

Speaking of the metadiscourse of communication as a condition of the nonviolent social order, we emphasize the continuous contextual framework of social space and time, the implicit semantic relationship in a society, which is concretized in the provisions of hermeneutics. The importance of the metadiscourse of communication is supported by all principles selected by Emilio Betti: autonomy of the semantic form, semantic coherence, relevance, and adequacy of understanding as "evaluative assigning of the meaning" (Betti, 1962).

The semantic unity of the communicative space of the society guides individual semantic expectations, intentions, objectives, and actions in a real situation. The existence of the metadiscursive semantic structure related to the maintenance of the nonviolent social order is emphasized by the following concepts: sociocode, archetype, chronotope, mental model, mentality, horizon of consciousness and also generalized communication codes - truth and power 
(Luhmann, 1979), local context (Giddens, 1986), habitus (Bourdieu, 1991), which determine the borders of understanding of what is happening. This implicit structure of "pre-knowledge" correlates with cognitive schemes that provide global semantic coherence in the society. On the other hand, cognitive schemes and conceptual models correlate with the process of thinking natural for humans. Mental models and frames, as well as signs are the subjects of communication in the semantic field, guiding the immediate recognition of image and grasp of the meaning. Thus, the contextual structure of "preunderstanding" and "preknowledge" has its own subjective topology, which is tied to the existing in the society conceptual framework, as well as to archetypes and ethnic stereotypes.

Signs, concepts, and expressions allocate a certain focus in the semantic field, which may be shifted in the process of understanding. Thus, focusing the metadiscursive semantics of spatiotemporal relations in literature, M.M. Bakhtin introduced the term chronotope believing that the entry into the sphere of meaning takes place only through the "gates of chronotopes." He associated the artistic value of chronotope with not so much physical space and time, as philosophical and social generalizations and ideas that are filled with "flesh and blood" in the artistic image allowing to build a capacious, figurative, emotional portrayal of events according to the real historical context (Bakhtin, 1975).

In the social theory, the notion of time-space is also intended to fix a specific historical context of the spatiotemporal unity of events. We associate the heuristic potential of the chronotope concept with combining the boundaries of the cultural and mental experience. Cultural tradition maintains chronotopes as the basic world perception attitudes in space symbolism determining the principle of organization and harmony of the world. In the cultural symbolism, the semantic context of chronotope is inextricably linked with the code of truth defining the logic of understanding.

Highlighting the metadiscursive level of communication, we emphasize the continuous contextual basis of ethnic consciousness and social space-time. The implicit semantic relationship in the society is provided by introducing metadiscourse in the practice of indirect communication provoking meaning generation (acquisition). The channels of metadiscursive influence on the mental dynamics of an individual may be both suggestion (hypnotic influence) at the direct emotional level of meaning perception and verbal practices at the cognitive level.

The implicit communication strategy of manipulation at the level of emotions is based on an involuntary suggestive mechanism of mental influence, the result of which is involuntary submission (which can be observed in a state of hypnosis or trance). The suggestive influence of one individual on another in the form of emotional infection, according to B.F. Porshnev, occurs prior to outlining of elementary meaning of an action, prior to the forms of communication as the transmission of messages (e.g. verbal), and prior to any kind of transformative (labor) activity. The unity of emotional experience, a single "universal" emotion, and suggestive communication are the basis for formation of the second signal system functions. This idea is supported with the fact that the oldest areas in the brain evolution are associated with the transmission of audio signals that have the greatest suggestive effect, are immediately understood without requiring interpretation (Porshnev, 1979).

The counter-suggestive manipulation mechanism is associated with the cognitive practice of indirect communication as thought communication and reflection in the direction of volitional intentions. However, the boundaries of freedom of thought are marked with the semantic macrostructure of the community.

Since humans live in a world of relations, the semantic behavioral continuum is its first and ever-changing reality, in which there is a struggle of "wills" for the implementation of certain opportunities. This virtual struggle is rather toughly continued in social interactions and conflicts. Time in the psychic reality does not coincide with the passage of time measured in the physical world. "Quanta" of this particular time constitute implicit communicative practices that are discursively developed in the form of processes of verbal speech, letters, documents, resolutions, sanctions, etc. in the physical time. In the game of wills, when one side tries to refuse to execute someone else's intention (suggestion), and the other -to make it to perform, the crucial role is often played by emotional pressure, behind which the complex phenomenon of negative emotions (e.g., guilt and resentment) stands, according to Papush (Papush, 1997). In this case, the metadiscursive influence is effected through provocation of stress of emotional links between people, which stands behind the actions such as assigning specific roles in a conflict, formation of "self-image", evaluative judgments as labels.

The processes of suggestion and counter-suggestion that unfold in the behavioral continuum are not observed and, therefore, are related to the scope of metadiscourse of communication. As pointed by M. Papush, one can see the support of the original inducement by additional influence, most often verbal, carrying a definite meaning with regard to the future interaction in the form of support or punishment. In this case, different voice practices implement the metadiscursive influence at the level of meanings generation using two types of suggestion (inducement, pushing in a certain direction -in psychology): requests and orders, and three types of counter-counter-suggestion: reference to the world order, reference to the socially fixed position (e.g., indisputable opinion of parents), promise of reward or threat of punishment. 
The cognitive practice of introducing metadiscourse is presented with the precedent-setting statements that create emotional expression and form a system of value-related orientations. The precedent-setting statements are based on the conceptual models that define the motives of social behavior.

An illustrative example of the introduction of metadiscourse is the practice of citing and throwing-in an unprecedented (sensational) statement, as is done in the technology "Overton Window", which allows changing the society's attitude to things that had previously been considered completely unacceptable. The discursive practice of citations assumes and hides the invisible struggle for the power of nominations, "the power in the sphere of notations", and, thereby, "for fundamental group values" (Bazylev, 2005). Valuable expansion is the content of indirect communication, which results in introduction of not always clearly pronounced (intentionally concealed) ideologeme or attitude. Practice of citation plays the role of the model of generation of existentially significant meaning within the boundaries of the concealed ideologeme. Citation as "someone else's word" (precedent-setting statement) activates imaginative and cognitive structures that affect the pattern of social behavior through the chain "interests - goals - style". Changing one element of speech in this chain can cause transformation of the paradigm of social behavior in the community, which provides the necessary emotional and semantic ground of trust to the authorities.

Metadiscursive influence in intersubjective practices is always implicit, but not removable, since the introduction of possible meaning in the space of thought communication enables its interpretation, but does not offer a way to eliminate the meaning. Just on this basis, we can say that signs and symbols rule the world generating meanings, and discursive practices are the weapons of mass effect in the formation of ethnic historical consciousness and mentality.

\section{Discussion}

A person is from his birth included in the community with thousands of invisible threads translating emotional connections that are unexpressed and unconscious. We believe that the natural basis of non-violent social order is best described by the ethical ethnic stereotype, in the formation of which a key role belongs to perception of place and time by the individual and the community. Individual's perception of time and space is linked to norms adopted in the ethnic community, which is in turn inscribed in the chronotope of the geographical environment -the landscape (including climate conditions). A norm defines the boundaries of the natural existence of a community, the basic orientations in the world perception, and the limits of the relations of individuals in a community.

Located at the intersection of the physical (geographic) space-time and the social, a man connects these measurements in an emotionally figurative picture of the life world, based on certain semantic basic orientations that determine the scope of the metadiscourse of communication in the community.

The primary cultural symbols determining the archetype and language of consciousness of the given community, according to modern authors, include myths containing symbols of elements (Mamardashvili \& Piatigorsky, 1999; Eliade, 1994, 2002). M. Eliade provides convincing evidence showing that the archaic man is defined by cosmic symbolism subconsciously even in his spatial orientations. His lifeworld is based on the specific sense of "sacred space", which has a special point -the "center of the world." This center is present and symbolized in various cultures ("cosmic axis", "sacred pillar", "world pillar", "eye of the sky"). Spatial orientations of parts of the world, location of dwellings, their organization, and social life are linked to it. Cosmic symbolism clearly manifests itself in the specific forms of cities, palaces, and temples, which are the images of the world. Eliade noted that these cosmological images and symbols form the habitable world of a man of archaic society, build a system of religious ideas and a model of religious behavior. The symbolic super-pragmatism of communication is so significant in an archaic community that even formal violation of the tradition changes the world and makes it impossible to exist in the world (Eliade, 2002).

Recognition by each individual of the unity of "We" forms deep and very persistent emotional basis of the community, which can also be treated as a prediscursive and metadiscursive condition of the nonviolent social order. "We" is perceived by each member of the community as a special reality bearing the moral law and imperative and is determined in modern literature with the terms: historical consciousness, mentality, ethnic consciousness.

L.N. Gumilev stressed that the determining factor of ethnic consciousness is not the language, the origin (in the sense of ethnicity), the material culture, the ideology, which can sometimes be the determining factor, and sometimes not. Sequential change of the perception of time reflects the rise and fall of ethnic integrity. He identified four stereotypes of the sense of time in the relation of ethnic group as a whole to the category of time: passeism, actualism, futurism, complete neglect of time (because for a common dweller, time counting does not make use for the activities that feed him) (Gumilev, 1994).

Ethnic stereotype forms an invisible metadiscursive channel of communication between generations. It involves translation of the norm of relations, the norm of perception of space-time, duty, honor, the sense of dignity and 
confidence, as well as the feeling of safety in the community.

For the European worldview, the linear perception of time is typical. In this case, the proclaimed goals and the real path of the community do not coincide. From the point of view of communitarianism, the future of the community is not an arbitrarily chosen path, but a path that leads to the implementation of joint public purposes by traditions and customs (Maclntyre, 1981). The role of rational choice is negligible, since the social attachments, which guide our behavior and determine our choice, are unwittingly acquired in the process of growing-up through belonging to the family or the community (Sandel, 1981).

The perception of time, goals, and means of achieving them are not the same for different generations. Shared goals and means considered within the context of generations as different time processes are partly superimposed on each other and swap their positions. In addition, the standards of justice defining the tacit condition of trust to the social order may vary depending on the traditions and lifestyle of specific social formations (Taylor, 1985, Macintyre,1981). Thus, the paradigm of the universal theory of justice that all generations (past, present, and future) are equal (Rawls, 1972) is broken when we put the goal in the future, and the means in the present. This arrangement of goals and means says that the existence of today's generation is a means for the welfare of future generations. Therefore obvious goals must be analyzed to determine whether they are hidden means for other purposes that are disguised as means (Fell, 2013).

The most important condition of the nonviolent social order, to our opinion, is the communicative practice of justification and recognition of the state legal power in accordance with the received code of truth.

In a certain space-time interval, the social order as the integrity of the cultural community and the state is based on two kinds of power: 1) state-legal power represented by the administrative system of management and constitutional regulations, 2) the "spiritual" power over the minds represented, to our opinion, by the trappings and artifacts determining the code of truth. In maintaining a stable state education, the code of truth is more important, though not always clearly articulated. Its social role is determined by the requirement of justification of the existing administrative power.

Reinforcement of the power of the elites depends much on the orientation of the mental dynamics of fellow citizens. The code of truth as the social order metadiscourse in this case is extremely important, because it determines the ideological orientation, the principle of the world order understanding and the social order included in the harmony of the world, which provides semantic support for justification and acceptance of the power by the mass consciousness. Thus, in the Middle Ages, the monarchical power was unshakable as it was justified for all members of the community as power given by God and blessed by the Church. And the priority right of the Church and ecclesiastical elite for the truth was never questioned.

Problematization of the code of truth in the current situation is associated not only with the traditional confrontation of two truths (faith and reason), but also with the aggravation of cultural confrontation in the course of globalization. Multiculturalism of the modern world exposes the social and existential significance of cultural traditions, despite the priority of the declared freedom of choice. The space of choice must be designated; a person should see from what and how he can choose. The role of semantic references of correct and legitimate inducements is played by the general codes of communication -the code of truth and the code of power (Luhmann, 1979).

The metadiscursive impact of the code of truth, though not clearly observed, but tangibly manifests itself in the practices of explanation, justification, conviction, and in the existential process of correlating "I - the physical world - the social reality".

The concept tradition to a certain extent concretizes the code of truth, which is associated with centering the physical and social space-time in the mind of an individual belonging to a particular cultural community. R. Guenon (Guenon, 2000) understood the criterion of truth as the intellectual doctrine, which is the basis for the tradition that suggests the value-related framework for understanding and emotionally accepting what is happening. Tradition is intrinsically authoritative, according to Habermas, because it contains a presumption of truth (Habermas, 2010).

With respect to the social order, tradition is correlated with the metadiscourse of communication because it defines, saves, and transmits the basic meanings and values in a certain structure of artifacts and activities of the subject. Compliance with tradition is a condition of intellectual and emotional involvement of a person in indirect communication, which is guided by certain symbolism having legal status. Herewith, the occurring percepts are not always clearly understood. This communication strategy does not limit the freedom of individual choice and at the same time points to the existing, though not expressed, semantic boundaries of understanding. M. Foucault believed that this hidden from direct observation network of relationships between words and things defines the characteristic of a particular era and culture codes of perception and cognition (Foucault, 1984).

Tradition has indirect semantic impact that plays a key role in pragmatic manipulation of consciousness and selfconsciousness of individuals. The natural combination of the individual consciousness with the general collective 
experience in the motivational-value dimension is accomplished through activation of archetypes, building epistemes, symbolic representations and kenotypes (super-representations oriented to the future - M. Epstein) in the process of not always perceived emotionally intense mental activity of finding the meaning.

\section{Conclusion}

The conditions of the nonviolent social order can be seen in ordering the systems of activity with certain norms and traditions. The nonviolent cultural mechanism for maintaining the social order is implemented in the practices of indirect communication, which are supported by archetypal basis and determined in the stereotype of behavior. This is the mechanism, with which the processes of cultural and personal identification that have aggravated in the information society are associated.

Natural grounds of the social order form a continuum and contextuality of the lifeworld of the society, the rootedness of semantic forms in the tradition and inner world of an individual. The substantiation and justification of power are the basic processes of legitimation of the social order and its stability. In summary, the archetype of the social order as a non-violent movement in the organization of community is the code of truth, with which the substantiation and acceptance of power on the basis of trust is associated.

Natural social order is closely related to the ethnic stereotype of behavior and perception of time. Change in the stereotype of behavior is largely determined by the practice of introducing metadiscourse, which in today's networked world is well demonstrated by the incremental discovery technology "Overton Window."

The metadiscursive practice of maintaining social order is represented by implicit processes of formation of mentality as subconsciously normalized ethnic consciousness. We cannot see the nonviolent mechanism for maintaining social order, but it is what keeps the community in spite of the ongoing political and cultural transformations.

Metadiscourse of communication fulfills the function of justification of power and psychoemotional defense. Transformations of the social order are made possible as a result of discursive revolutions shifting the basic semantic and value-related references embedded in the subconscious by traditional education.

\section{References}

Animitsa, E.G., \& Sharygin, M.D. (2005). Spatiotemporal paradigm in geography. Geographichesky Vestnik, 1-2, 11-14.

Bakhtin, M.M. (1975). Forms of time and chronotope in novels. Essays on historical poetics. Questions of literature and aesthetics (pp. 234-407). Moscow: «Hudozestvennay literatura».

Barzel, Y. (2001). A theory of the state. New York: Cambridge University Press.

Bassin, M. (1991, Spring). Russia between Europa and Asia: The Ideological Construction of Geographical Space. Slavic Review, 50, 1, $1-17$.

Bazylev, V.N. (2005). Political discourse. Effective communication: history, theory, practice: Dictionary - reference (Eds., Panin, M.I., pp. 697-701). Moscow: ACT: Olimp.

Betti, E. (1962). Die Hermeneutik als allgemeine Methodik der Geisteswissenschaften. Tübingen: J.C.B. Mohr .

Bourdieu, P. (1991). Language and Symbolic Power (Thompson, J.B., Ed.; Raymond, G., \& Adamson, M., Trans., pp. 105). Cambridge, Mass: Harvard University Press.

Bueno de Mesquita, B., Smith, A., Siverson, R.M., \& Morrow, J.D. (2003). The logic of political survival. Cambridge, MA: MIT Press.

Castells, M. (1996-1998, 2000-2004). The Information Age. Economy, Society and Culture (First edition 1996-1998, Second edition 2000-2004). Oxford; Malden, MA: Blackwell.

Dijk van, T.A., 2008a. Discourse and context. A sociocognitive approach (digitally printed version 2010, pp. 287). New York: Cambridge University Press.

Dijk van, T.A., 2008b. Discourse and Power (pp. 308). New York: Palgrave Macmillan.

Eliade, M. (1994). The sacred and the profane. Moscow: Izdateljstvo MGU

Eliade, M. (2002). Occultism, witchcraft, and fashion culture (pp. 224) Kyiv: "Sofia"; Moscow: Publishing House "Helios".

Fell, E. (2013). Communication between generations it terms of modern philosophic and social theories. Philosophy of communication: Problems and prospects: monograph (Edited by Klyagin, S., Doctor of Philosophy, Professor, and Shipunova, O., Doctor of Philosophy, Professor, pp. 43-50). St. Petersburg: Polytechnic University Publishing house.

Foucault, M., 1984. The order of discourse. In: Language and politics (pp. 108-138). London: Basil Blackwell.

Fukuyama. F. (1996). Trust. The Social Virtues and the Creation of Prosperity (first published 1995, pp. 480). Free Press.

Gadamer, H.-G. (1975). Truth and Method (Second, Revised Edition. Translation revised by Weinsheimer, J., \& Marshall, D.G., pp. 637). Sheed \& Ward Ltd and the Continuum Publishing Group.

Giddens, A. (1986). The Constitution of Society. Outline of the Theory of Structuration (pp: 440). Cambridge: Polity Press.

Glebov, S. (2010). Eurasianism between the Empire and Modern (pp. 113-114). Moscow: Novoe Isdateljstvo

Grossman, L. (1977). Man-enviroment relationship in anthropology and geography. Annals of the Association of American Geographers, 
67, 126-144.

Guenon, R. (2000). Essays on tradition and metaphysics. St. Petersburg: «Azbuka».

Gumilev, L.N. (1994). Ethnogenesis and biosphere of the Earth. Volume \#3. International Almanac. (pp. 544). Moscow: Tanais DI-DIK. Hägerstrand, T. (1975). Space, Time and human conditions. Farnborough: Saxon House.

Habermas, J. (1983). Moralbewußtsein und kommunikatives Handeln. Frankfurt am Main: Suhrkamp.

Habermas, J. (2010). Problem of late capitalism legitimization (p. 264). Moscow: Praksis.

Hay, D. (1968). Europa: The Emergence of an Idea. Edinburgh: Edinburgh Univ. Press.

Hosking, G. (2002). Why We Need a History of Trust. Retrieved 2015, February 20 from http://www.history.ac.uk/reviews/review/287a

Inkeles, A. ( 1950). Public Opinion in Russia. Cambridge: Harv.Univ.Press.

Klyagin, S.V. et al. (2014). Modern communication sciences: Social practices as words compatibility (Logunov, A.P., Ed., pp. 200). Moscow: LENAND.

Kozhemyakin, E.A. (2011). Discourse barriers of social dialog: subjectively pragmatic incoherence. Metadiscourses of communication and problems of social dialog. Collection of articles (Klyagina, S.V., Doctor of Philology, Professor Shipunova, O.D., Ph.D., Professor, Eds.). St. Petersburg: the Publishing House of the Polytechnical University.

Maclntyre, A. (1981). After Virtue: A Study in Moral Theory. London: Duckworth.

Mamardashvili, M.K., \& Piatigorsky, A.M. (1999). Symbol and consciousness. Moscow Shkola "Yaziki russkoi kultury".

Manovich, L. (2001). The Language of New Media. Cambridge, MA: MIT Press.

Matheson, D. (2005). Media discourse: analyzing media texts. L.: Open University Press.

McLuhan, M. (1967). "The Timid Giant" in "Understanding Media: the Extensions of Man" (pp. 329-343). London, England: Sphere Books Limited.

Moores, Sh. (2012). Media, Place and Mobility. Basingstoke: Palgrave Macmillan.

Morley, D. (2007). Media, Modernity and Technology: The Geography of New. L.: Routledge.

Myerson, R.B. (2008). The autocrat's credibility problem and foundations ofthe constitutional state. American Political Science Review, 102 (01), 125-139.

Luhmann, N. (1979). Trust and Power. Chichester, John Wiley \& Sons.

North, D.C., Wallis, J.J., Webb, S.B., \& Weingast, B.R (2007). Limited access orders in the developing world: Anew approach to the problems of development. World Bank Policy Research Working Paper 4359.

North, D.C., Wallis, J.J., \& Weingast, B.R. (2009a). Violence and Social Orders: A Conceptual Framework for Interpreting Recorded Human History. Cambridge University Press.

North, D.C., Wallis, J.J., \& Weingast, B.R. (2009). Violence, natural states, and open access orders. Journal of Democracy, 20(1), 5568.

Olson, M. (1993). Democracy, dictatorship, and development. American Political Science Review, 87 (3), 567-575.

Papush, M. (1997). Practical psychotechnics (pp. 174). Moscow: Institut gumanitarnay issledovany.

Petrov, M.K. (2004). Language, sign, culture (pp: 328). Moscow: URSS.

Porshnev, B.F. (1979). Social psychology and history (pp: 232.) Moscow: Nauka.

Porshnev, B.F. (1971). Counter-suggestion and history (basic social-psychological phenomenon and its transformation in human development). History and Psychology (pp. 7-35). Moscow: Nauka.

Ragulina, M.V. (2013). Integrated paradigm in the cultural geography of the XXI century. Basic Research, 10-14, 3149-3152.

Rawls, J. (1972). A Theory of Justice. Oxford: Clarendon Press.

Ricœur, P. (1974). The Conflict of Interpretations: Essays in Hermeneutics (Don Ihde, Ed., Domingo, W. et al. Trans.). Evanston: Northwestern University Press.

Sandel, M.J. (1981). Liberalism and the Limits of Justice. Cambridge: Cambridge University Press.

Savitsky, P. (1921). Turn to the East. Exodus to the East. Sofia.

The Idea of Europe; from Antiquity to the European Union (Pagden, A., Ed.). Washington, D.C.; Cambridge, N.Y.: Woodrow Wilson Center Press; Cambridge University Press.

Taylor, Ch. (1985). Human Agency and Language: Philosophical Papers 1. Cambridge: Cambridge University Press.

Wintle, M. (1999). Renaissance Maps and the Construction on the Idea of Europe. Journal of Historical Geography, Vol. 25, 2, 137-166.

Wolff, L. (1994). Inventing Eastern Europe: the Map of Civilization on the Mind of the Enlightenment. Stanford, Ca.: Stanford Univ. Press. 